\title{
Neoliberalism, the Knowledge Economy, and the Learner: Challenging the Inevitability of the Commodified Self as an Outcome of Education
}

\author{
Fiona Patrick \\ School of Education, University of Glasgow, St. Andrew's Building, 11 Eldon Street, Glasgow G3 6NH, UK \\ Correspondence should be addressed to Fiona Patrick; fiona.patrick@glasgow.ac.uk
}

Received 28 February 2013; Accepted 4 April 2013

Academic Editors: T. A. Betts, T. Carvalho, and R. Pasnak

Copyright (C 2013 Fiona Patrick. This is an open access article distributed under the Creative Commons Attribution License, which permits unrestricted use, distribution, and reproduction in any medium, provided the original work is properly cited.

\begin{abstract}
Neoliberalism is now a globalised agenda that underpins educational strategy and policy in many nations. The evolution of the concept of the knowledge economy and of the knowledge worker has been allied to the rise of neoliberalism as an end with respect to educational processes. This review article considers the ways in which constructs of the knowledge economy within a neoliberal agenda have given rise to specific discourses and conceptualisations of educational outcomes and aims. In particular, the value of knowledge and learning within neoliberal constructions of education will be discussed. The positioning within these constructions of the learner as a reification of economic capital will also be explored. This paper argues for a reconsideration of the purposes of education if the commodified self is to be resisted.
\end{abstract}

\section{Introduction}

There is a considerable body of literature which explores the effects of neoliberalism on education policy and practice [15]. Despite this body of critique, neoliberalism has moved beyond a hegemonic set of discourses and practices to achieve the status of a doxa, that is, "an unquestionable orthodoxy that operates as if it were the objective truth" [6, page 419]. In addition, neoliberalism can be coupled with another set of discourses: those of globalisation and the knowledge economy. Taken together, these three ideological constructs exert considerable shaping force on education systems in many developed and developing countries to the point where it can seem futile to argue that their effects may not constitute either educational or economic good.

However, it is important to continue to raise questions about the influence of neoliberalism on educational aims, policies, and processes. Without this exploration there is a risk that neoliberal ideologies will remain entrenched while the aims of education are eroded to a set of functionalist outcomes. To consider these issues, this review article will discuss the ways in which neoliberalism as a globalised ideology interacts with constructs of the knowledge economy to give rise to specific conceptualisations of educational outcomes and aims. In particular, the commodification of education and the commodification of the learner as potential knowledge worker will be of interest. Despite the depth of literature on neoliberalism, there is a need to consider further how neoliberal policy shapes the selves of learners and how these selves are positioned within the overall aims of education. This is an important aspect of contemporary debate, given the continuing tendency for neoliberal policy to position individuals as future workers [7] and to assert the primacy of education as the means to this end.

\section{Conducting the Review}

The value of reviewing a mature topic such as neoliberalism and its influence on education lies in the opportunity to reconsider aspects that warrant fuller understanding [8]. To enable this, an analytic literature review was conducted to explore and extend existing theory [9] relating to neoliberalism and the knowledge economy. Initially, the review was carried out following four research stages to search, map, clarify, and appraise the literature [10] across a range of peer-reviewed texts. A qualitative analytic approach [11] was 
then used in the critical reading of the texts to identify the conceptual framework and the content that would form the basis of the review article. This identification was conducted by use of a concept matrix [12]. Concepts and theories were categorised by specific units of analysis pertaining to organisational, individual, and policy domains.

Once saturation of concepts was reached, a summary of the main themes and underlying constructs was mapped in its final version. Two global themes were identified: firstly, neoliberalism, the knowledge economy, and the commodification of learning, and secondly, the learner as subject and subjectified. The theoretical framework for the discussion was then drawn from Foucault's analysis of subjectification $[13,14]$ and, following from this, Bevir's [15] construct of individual agency. Biesta's [16] concept of education as a means to support students" "coming into presence" was also included in the analysis. It may be that a clearer focus on the development of intellectual and affective capacities that can support children to "come into presence" and more fully realise their potential might enable the development of educational processes that can counteract the tendency in the market model to commodify learning and learners.

\section{The Value of Neoliberalist Learning: Utility, Function, and Commodity}

Neoliberal forms of governance have attained transnational hegemonic status [17, page 395], resting on governance of regions, groups, and individuals through specific policy approaches such as decentralisation, privatization, and individualisation [17]. The origins of neoliberalism have been well discussed in numerous papers (see, e.g., Centeno and Cohen [18], Hursh and Henderson [19], and Peters [20]) and so will not be reprised here. The important point with respect to this discussion is that neoliberal policy has displaced liberalism as a dominant political ideology with the aim of transferring economic control from governments to private markets [18]. As Olssen comments, neoliberalism refers to "a particular economic model, which ... pertains to the way that practices of economics and discursive patternings of knowledge and learning interact" [21, page 217]. Within neoliberal doctrine, the market becomes the central organising principle for political, economic, and social decision making [7].

However, as Major notes, "[c]onfusion and ambiguity continue to plague the concept of neoliberalism despite its frequent use in characterizing transformations in both national and international political economy" [22, page 538]. Further confusion is apparent when the concept is used to characterise education policy and practice, with the construct of neoliberalism having been appropriated from a descriptor of modes of global economic governance [22] to be applied to global education governance. Despite this confusion, it can be argued that neoliberalism in education policy tends to engender a technical rationalist approach to knowledge and its value [23, page 509]. Education has been incorporated into an agenda of wealth production at nation state level via discourses relating to the knowledge economy [24], the knowledge society, and, more recently, the enterprise society [23, page 509].

Peters [20] argues that the knowledge economy should not be thought of merely as a neoliberal notion but as having powerful descriptive and analytic force in its own right [20, page 68]. The term knowledge (based) economy emerged in the early 1990s but remains contested: to speak of the knowledge economy as a coherent theory or set of theories is inappropriate, although different theories do share some core understandings. For example, the assumption that education will be a driver for economic growth, development, or improved competitiveness for nations under globalised market conditions is found in many explanations of the knowledge economy [25].

Peters [25] believes that we have now entered a phase of knowledge capitalism. This shift has also been characterised as cognitive (bio)capitalism [26] in that the knowledge economy is based on constructs of immaterial (intellectual and affective) labour rather than physical labour as the basis of production [27]. The key aspect to this latest phase is an extension of the importance of intellectual and symbolic goods in the economy [27]. Within both neoliberalism and the idea of the knowledge economy rests a concept of each individual as being economically responsible and "economically self-interested" [2, page 314]. Phillips and Ilcan argue that the onus is now placed on individuals to "become self-regulating ... and market-knowledgeable" [17, page 397].

Following Drucker's work, Peters and Reveley argue that the intellect of each knowledge worker has become the most important productive resource [28, page 4]. Individuals carry the mode of production within them, and shaping the individual intellect must therefore take place through education towards the end of developing human capital and economic growth [28, page 4]. The value of knowledge within this paradigm inheres in its utility to develop human capital [21, page 222]. Thus the role of schools and universities in relation to educating the individual has changed markedly in the last thirty years: the end of education can be considered as the creation of the knowledge worker.

3.1. The Individual and the Ends of Neoliberal Education. In the United Kingdom, there has been a strong trend in education policy and practice towards the acceptance of neoliberal doctrine. This has led to a reconsideration in which educational aims are most valuable for individuals and for the economy (see $[29,30])$. Neoliberalism also presupposes a "transformation in the relationship between education and social justice" [31, page 28]. Given access to education, a core neoliberal assumption is that all can succeed regardless of sociocultural contexts. There is a tendency for neoliberal ideology to assert that

Children from wealthy backgrounds no longer have an unfair advantage over children from disadvantaged backgrounds, because of the international character of the labour market. What holds back the children from disadvantaged backgrounds is not the fact that those from privileged backgrounds enjoy all the educational advantages, 
but their lack of credentials, knowledge and skills which prevent them from competing in the global competition for high-skilled, high-wage employment. Therefore, a "fair" educational system is no longer one that attempts to create a level playing field but one dedicated to raising the standards of all, and facilitating greater access to higher education in order to arm the workforce with the credentials, knowledge and skills that are valued in the global labour market. [31, page 28]

In addition, the learner as future knowledge worker [7] should also take responsibility for their learning throughout their educational career while showing an adaptable approach to job seeking and reskilling in an employment market characterised by uncertainty and career instability.

The characteristics of the responsible, successful, and adaptable learner are set out in the English National Curriculum [29]. The National Curriculum states that, by the end of their school education, children should be

(i) successful learners who enjoy learning, make progress and achieve,

(ii) confident individuals who are able to live safe, healthy and fulfilling lives,

(iii) responsible citizens who make a positive contribution to society [29, no page number].

These aims bear a strong similarity to those in the Scottish Curriculum for Excellence (CfE). CfE's aims are grouped under the "four capacities" which represent the outcomes of schooling that children will be successful learners, confident individuals, responsible citizens, and effective contributors [30, no page number]. Priestley and Humes [32] state that there is little attempt in the Curriculum for Excellence to "unpack" these concepts or to delve into the "deeper, underlying purposes of education. In the various CfE documents, there is hardly any mention of the big philosophical and sociological matters which ... are a necessary precursor to planning a curriculum" [32, pages 353-354]. Curriculum for Excellence positions a set of capacities that have no more claim as the end of schooling than any other set of dispositions or skills but have everything to do with shaping the individual as economically responsible and entrepreneurial. Knowledge within these curricular statements has largely been conceptualised as skills for (knowledge intensive) work and for life in the knowledge economy.

In terms of higher education in the United Kingdom, universities are now regarded in neoliberal policy as producers of knowledge and the products of knowledge that can enhance individual and collective human capital and so positively affect economic growth and development. That universities have an important role with respect to the development and dissemination of knowledge is not a new idea [33]. However, the concept of the university's role within what has been called academic capitalism [34] demonstrates a change in recent times towards a more functional and marketised view of the value of academic knowledge and work [33, page 185]. Within this vision, universities are regarded as one of the main agents of knowledge production in a knowledge society. However, emphasis tends to be placed on the production of knowledge that can be commercially exploited rather than on considering the ways in which engagement with knowledge can enhance individual development within sets of broadly conceived educational aims.

Arguably, the acceptance of marketisation and associated forms of neoliberal governance has led to the undermining of universities as "independent source[s] of knowledge and inquiry" [33, page 192]. One of their primary functions is now to

Raise their own productivity in order to survive. They must package knowledge, deliver flexible education through ICT, provide adequate training for "knowledge workers", and produce more of them at lower unit cost. While this scenario portrays universities as guiding social change, there is evidence of a reverse tendency: that they are becoming subordinate to corporate-style managerialism and income-maximization. [35, page 3]

A result of this emphasis is that universities are no longer considered primarily as "cultural spaces" that can enable individual students and teachers to engage in critique and discussion [3, page 495]. Education tends not to be considered as a public or individual good in any meaningful sense [3, page 494]. It is simply a commodity, much like any other, and higher education (both as a sector and as individual institutions) seems to have lost any will to debate openly the values and goals that students might develop [36]. There is little sense of an alternative to the neoliberal vision of the purposes of education as creating the "economically selfinterested" individual [2, page 314].

Cribb and Gewirtz claim that universities have now become "hollowed out," lacking any "distinctive social role and no ethical raison d'etre" [37, page 3, original emphasis]. Neoliberalism seems to have "taken away the joy of learning, the creativity of teaching and the formation of strong public intellectuals" [5, page 489]. Educational institutions have become part of a social reality that is "identified with an economic value system that shapes all reality in its own image" [23, page 502]. Within this value system, knowledge becomes "objectified, measurable and transferable" [23, page 506]. One effect of this is that credentialism becomes inherent in the system: the more credentials possessed in the shape of certificates and degrees, the more marketable the individual. The self as learner becomes tied to "an economic empirical base" [23, page 517]. However, as higher education sectors have expanded, the value of credentials has lowered rather than increased [31]. Graduate oversupply is now a characteristic of the job market in the United Kingdom as is the driving down of graduate wages [31].

In addition, disciplinary forms of knowledge become credited with differing economic and practical value. The applied sciences together with information and communication technologies are raised in status with regard to assumed economic utility rather than the arts and humanities. Nussbaum argues that the arts and humanities become feared by 
those who educate for economic growth, because it is "easier to treat people as objects to manipulate if you have never learned any other way to see them" [38, page 23]. When knowledge is seen as having different levels of economic value, and when that economic value becomes predominant, the complexities of defining the heuristic, epistemological, and ontological value of knowledge as a socially constructed phenomenon are lost [39]. This is seen all too clearly in discourses of the knowledge economy in which the word knowledge is used "in an almost entirely rhetorical way; the meaning of knowledge is at best implicit and at worst virtually empty of content" [40, page 193].

Differential value also accrues to individuals as knowledge workers, their value being linked to the world of immaterial labour within which knowledge is the valorized commodity [26]. Fumagalli argues that within the knowledge economy, "[p] roductive activity is increasingly based on immaterial elements, that is to say, on intangible "raw materials," ... which come directly from the utilization of the relational, sentimental, and cerebral faculties of human beings" [26, page 10]. However, this does not bring the individual knowledge worker power over the products of their intelligence, nor does it bring them increased agency or autonomy in their work [31].

Of concern, here is the way in which neoliberalism and the knowledge economy are presented in global and national policy as inevitable aspects of modern capitalist economies. The trend in neoliberal policy to reposition the individual within a framework of economic utility and knowledge capital can seem irrevocable. However, as Torres argues, neoliberalism has "utterly failed as a model of economic development" [33, page 193]. Neoliberal rationality is now acknowledged to have contributed to the 2008 financial crisis [22] through creating conditions of global economic governance which led to the emergence of "devastating forms of financial instability” [22, page 537]. Yet, as Cahill [41] highlights, claims that the financial crisis might signal a revisioning if not an end to neoliberal hegemony were overstated: neoliberalism remains in the ascendancy. Cahill argues that this is because neoliberalism is embedded ideologically and discursively at national and global policy level, at institutional level, and at the level of social class relations [41, pages 486487]. He concludes that the ideologically embedded nature of neoliberalism "means that a generation of policy makers has only known neoliberalism as the common sense frame for conducting and evaluating policy" [41, pages 486-487].

There are signs that, in terms of labour relations and in terms of social movements, neoliberal economic policy is being challenged [41]. For example, resistance has come from individuals in trade unions, from student bodies, and from gatherings of citizens in protest at the austerity measures undertaken by governments in the United Kingdom and Greece [41, page 488]. As Cahill says, these challenges may not dismantle neoliberalism, but

[i]n the current context, even just halting further neoliberalisation would be a welcome development. It would stymie the practice whereby capital and political elites force the costs of the crisis onto labour. It would also halt the forcing of people into greater levels of market dependence for their basic needs by maintaining current levels of decommodification. [41, page 489]

Cahill [41] concludes that decommodification requires economic, social, and employment strategies that would enable socially protective rather than socially destructive policy to be enacted. Moving from neoliberalism to consider other economic alternatives is a laudable aim but, as part of this aim, there needs to be reconsideration of the effects of commodification in education, particularly at the level of the individual learner.

3.2. The Learner as Commodified Subject. Staddon and Standish [42] consider the changes in higher education in the United Kingdom as constituting a profound shift towards a competitive system within which students are placed within a paradigm of "customer orientation" [42, page 631]. A utilitarian conception of knowledge dominates a system in which quality of learning is judged by the cost-effectiveness of the delivery and by student perceptions of the quality of their learning experiences [42]. However, taken as part of the knowledge economy rhetoric and practice, it is not just knowledge within higher education that is reduced to utilitarian value, but the student as embodiment of that knowledge. The student as a person is commodified within the system. Overall, neoliberal concepts of (human) capital require "selves which are endlessly adaptable to the levels of change and insecurity, to the personal and social instability generated by a globalised economy" [43, page 353].

Of course, educational practices have never been neutral and have always acted upon students as selves with the aim of shaping intellect, emotions, habits, and so forth. However, neoliberal discourse tends to deride notions of the individual good as an aim of education: students are consumers and disciplinary knowledge is what is consumed. Even pedagogies which seemingly offer the learner autonomy and choice are not without issue. For example, Vassallo [44] highlights the growth of self-regulated learning in school and university contexts. Seemingly allied to the idea of learner empowerment, self-regulated learning can instead be thought of as being "entangled in the politics of control, conformity, obedience and oppression" [44, page 2]. The term self-directed learning is indicative of a shift in language use, from education to learning, from teaching to facilitation [16]. This shift has arisen from a range of influences, according to Biesta [16]: from constructivist and socio-cultural theories of learning, from postmodernism's positioning of the "end of education," and from the rise of neoliberalism [pages 5657]. Within the new language of education, the teacher is there to meet the needs of the learner [16], but these needs are narrowly defined as "learning" needs within a model that reduces learning to a series of teaching inputs designed to meet prespecified outcomes.

The economic rationalism underlying neoliberal educational policy tends to act upon individuals through use of specific discourses aimed (wittingly or unwittingly) at 
governing the self [5]. In this way, learners become commodified. Having said this, care must be taken not to refer to commodification as a relentless force "imposing an external will upon the unwilling victim" [45, page 200]. In theory, individuals still have agency to accept, reject, mediate, or ignore neoliberal policies and practices. In practice, the extent to which individuals can exert choice over whether to accept or resist such policies may be limited by a range of factors (social, economic, and cultural). Where individuals learn or work within a system that has embraced neoliberal educational ideals, a sense of isolation and helplessness may occur in the face of policy and management practices which predicate economic rationalism over the needs and talents of individuals.

Taking a Foucauldian perspective, the subject of the neoliberal project can be seen as the entrepreneurial self [43, page 355]. Foucauldian constructs of the subjectivity of the self have been the focus of much academic writing in the past ten years, almost to saturation point. Yet it would be a pity to overlook what he has to say on the ways in which power is enacted, and how it acts upon, individuals, for his concepts in this respect still have much to offer [23]. In particular, Foucault's work supports understanding of how individual subjectivity is constituted by discourses of power [46].

Bonnett argues that neoliberal educational practice is concerned with shaping the "selves of learners in accordance with what are perceived to be current economic imperatives, rather than, say with what arises from their sense of their own existence" [46, page 358]. Foucault suggests that our problem as individuals is to "discover that the self is nothing else than the historical correlation of the technology built into our history" [13, page 222]. The issue then becomes how to change these technologies [13], in which case, "one of the main political problems would be ... the politics of ourselves" $[13$, page 223]. It is tempting to concur with the Foucauldian perspective that power is inescapable, and that the best that remains to us is to develop the will not to be "governed like that, in this way" [14, page 75]. Ball and Olmedo [47] point out that concurring with this view does not mean accepting that the individual cannot offer resistance to subjectification. Indeed, power is not always a negative force according to Foucault [23]. Reading the subtleties of his conception of power enables us to see that there is room in the Foucauldian perspective for individual empowerment: as Ball and Olmedo state, "to define ourselves according to our own judgements ... to develop a particular technology of the self according to our own principles, an aesthetics of the self" [47, page92, original emphasis]. It is this thought that opens possibilities for individuals to reclaim themselves.

\section{Challenging the Doxa: The Possibility of Defining Ourselves}

The doxa of neoliberalism remains largely intact in education policy and practice in the United Kingdom, despite challenge at a theoretical and social level and despite a lack of empirical evidence of the economic or educational efficacy of neoliberal doctrine [48]. Wolf [48] notes the "marked absence" of clear education effects on the economic performance of any nation. She concludes that for something

which is supposed to be so powerful a promoter of economic growth, it is extraordinary how many studies find no relationship between increases in schooling levels and growth. Indeed, some studies based on extensive data-sets, actually find a negative relationship. [48, page 321]

A link between education and individual or systemwide productivity cannot therefore be assumed. However, if evidence from empirical research has not challenged the doxa, what can?

Wacquant [49] argues for resistance to neoliberal policy through a marriage of epistemological and social critique that questions "established forms of thought and established forms of collective life" [49, page 97]. Powerful critique of neoliberalism exists but tends to be "enclosed in and suffocated by the academic microcosm" [49, page 99]. Thus, its power to lead change is generally weak, particularly in terms of challenging the dominance of major international organisations (such as the World Bank, the OECD, and the World Trade Organisation) that sustain neoliberal economic policies and practices [49]. Wacquant suggests that the answer to the continued hegemony of neoliberalism lies in providing more critique and radical questioning [49]. Endless critique without widespread change suggests a somewhat pessimistic picture in terms of how neoliberalism might be supplanted. Where, then, does this leave the individual in terms of the (re)formation of the self?

Perhaps the beginning of an answer lies in a rethinking of the aims of education and the individual's place within any education system. As Down [7, page 59] argues, it is important to consider the possibility of the restoration of "human sensibility" in educational conversations, rather than economic rationalism, so that the process and purposes of education can be reimagined. Nussbaum's thesis might also be considered that a worthwhile conception on which to base education is that it should enable individuals to lead "meaningful lives" [38, page 23]. There are various ways in which the meaningful life can be thought of in terms of providing a basis for the aims of education. For White, one of the main aims of education should be "to help students to lead personally fulfilling lives" in the sense of supporting the development of capacities, knowledge, and understandings that will enable them to attain and maintain a sense of wellbeing [50, page 442]. As White states, the educational market brings with it "an ethical conception of the final ends of human life" locating these in the pursuit and gain of individual preferences exercised through choice [50, page 446, original emphasis]. This seems an impoverished vision. Wellbeing is not just about satisfying wants and preferences. It rests on a much more complex set of psychological, affective, and social factors through which individuals can create a sense of meaningful existence beyond economic utility [51]. Ryan et al. [51] link wellbeing to self-determination theory and to eudaemonia. In their understanding, wellbeing is not the result of hedonia-the experience of happiness as an 
occurrence of positive affect and absence of negative affectbut rather of living a "complete" human life in terms of the realisation of human potential [51]. Self-determination theory suggests three basic human needs: for autonomy, competence, and relatedness [52]. Ryan et al. argue that living well in the sense of eudaemonia requires the development of capacities such as reflectiveness and reasoning [51, page 145] as well as volition, autonomy, and mindfulness [51, page 146]. An education that can help children to develop these capacities might be based on contexts that allow children to experience a sense of being valued, a sense of trust, and a prosocial school and classroom environment rather than one based on individualism and competition [51, page 165].

The caveat to this, and it is a serious one, is that individual capabilities to become self-determining and to flourish depend crucially on socioeconomic contexts. Children come to school already affected by differences in their abilities to engage with learning because of factors arising from social and economic inequality. Lack of socioeconomic justice delimits the extent to which children will be able to develop capabilities to their fullest extent. For many children, having a positive sense of themselves as capable (in any domain) has begun to be closed down by life experience before the point of entry to school. This sense of self is then further impacted upon by a system predicated on views of successful learning as the meeting of outcomes, the passing of tests, and the expectation of compliance with a regulatory educational habitus.

If it is to be argued that individual wellbeing, or eudemonia (as flourishing), is a valuable aim of school and university education, should it be based primarily on constructs of autonomy in relation to a theory of self-determination? It may be more fruitful to think of education as enabling agency in the sense of individuals having the capacity to make informed decisions about their lives and to choose well (in the sense of making beneficial choices which do not negatively have impact on themselves or others, and which act for the individual and/or collective good). Bevir [15] makes an important distinction between autonomy and agency and argues for the importance of the latter. Bevir suggests that individuals cannot be autonomous in the strictest sense of the word [15]. Since individuals are social constructs, following a Foucauldian perspective, they live in a society in which power is "ubiquitous" [15, page 66]. Individuals as subjects are therefore constituted always through regimes of power [15]. Yet this does not mean that they can never exercise some power, in the sense of agency, over their own actions and their own choices. In as much as the individual as subject can be constituted by "practices of subjection" they might also be constituted by "practices of liberation" [15, page 65]. Even to adopt a construct of autonomy following liberal conceptions of the aims of education leaves open the argument that autonomy (or the lack of it) is less the result of educational processes and more the result of social conditions [53] and of internal psychological states [52].

The same argument may be levelled at agency as an aim of education-but agency can be considered to be something that a subjective sense of wellbeing requires. Agency, in short, is one element that enables individuals to develop a sense of self [54]. The agentic self is one who can resist "strong social suggestion through locating a position and role within social practice which is consistent with individual subjectivity and identity" [54, page 12]. One aim of education might then be to support the development of agency and agentic behaviours. Clegg [36, page 94] makes an important point about successful learning enabling individuals to imagine futureselves and to consider the role of knowledge in helping them to develop those selves.

To do this, education practices should be developed from a complex model of learning which takes account of the ontological, heuristic, and epistemological bases of knowledge. In addition, education should be reoriented towards human development in a broadly-based sense, rather than reduced to skills acquisition. Biesta suggests that:

\begin{abstract}
[w] hile learning as acquisition is only about getting more and more, learning as responding is about showing who you are and where you stand. It is about what I have called elsewhere a process of "coming into presence"... If education is indeed concerned with subjectivity and agency, then we should think of education as the situation or process which provides opportunity for individuals to come into presence, that is, to show who they are and where they stand." [16, page 62]
\end{abstract}

Education that enables coming into presence is about valuing diversity of opinions while questioning and exploring these opinions, it is about listening as well as contributing, it is about asking difficult questions that may have no conclusive answers, and it is about valuing other selves as much as we value our own [16, page 63]. In supporting students to develop their own emergent selves, "it becomes clear that the first responsibility of the teacher is a responsibility for the subjectivity of the student, for that which allows the student to be a unique, singular being" [16, page 63].

\section{Concluding Thoughts}

In order to reclaim education from neoliberalism, one place to begin might be to focus on education as the development of the self, not in accordance with economic imperatives but in accordance with wellbeing and individual flourishing as core aims of education. If education is considered as a transformation of the self of the learner, we may ask what are the processes of teaching and learning that will support individual intellectual, psychological, emotional, and social flourishing? Only in asking this kind of question we might be able to understand how agency can be encouraged in practice-partly as resistance to neoliberalism, but more with the aim of individual wellbeing at its heart. For this is where the real shame of neoliberalism lies: in terms of educational aims, the needs of the individual as a human being have been subjugated to the needs of capital and the economy. Rather than the shaping of learners' selves in accordance with "what are perceived to be current economic imperatives," schools, colleges, and universities should support practices that enable individuals to develop in ways that are consonant with "their sense of their own existence" [46, page 358]. 
The ways in which teachers in all education sectors can support these practices is open to debate, but debate needs to be there if neoliberal educational practices are to be rethought. One site of this debate should be in universities generally, and in teacher education institutes specifically. Through engagement with debate on what the aims of education should be-rather than acceptance of a set of curriculum assumptions about these aims-teachers might be encouraged to consider deeply and critically what education is for in terms of individual children and young people. Educators should be encouraged to realise that they have a choice of whether or not to accept neoliberal education practices at the classroom level. Curricula may be set, examinations and tests may dominate, but teachers' individual pedagogic choices and classroom cultures need not be beholden to neoliberalist ideology even though this doctrine continues to shape wider education policy. There is much that can be done to encourage pupils and students to think, to be critical, and to imagine possible selves. It is the sense of education enabling the development of human selves that holds possibilities for engendering humane approaches to education and learning in schools, colleges, and universities.

We can place human development at the heart of learning through the humanities, and perhaps we should pause to remember why the humanities were and are so called, even if it has become unfashionable to champion liberal education rather than more radical approaches such as critical pedagogy. But we can place human development at the core of all curricular areas. It is time to reclaim teaching across the disciplines, and this reclamation can be done at the level of the individual educator. While the agency of individual students needs to be valued and reasserted, so too does the agency of teachers. They are teachers who can make pedagogic choices that will benefit their students by enabling the development of individual capabilities with a view to enhancing individual agency and wellbeing. Perhaps it is not just the self of the learner that has to be reclaimed, but the self of the teacher.

\section{References}

[1] H. A. Giroux, "Neoliberalism, corporate culture, and the promise of higher education: the university as a democratic public sphere," Harvard Educational Review, vol. 72, no. 4, pp. 425-463, 2002.

[2] M. Olssen and M. A. Peters, "Neoliberalism, higher education and the knowledge economy: from the free market to knowledge capitalism," Journal of Education Policy, vol. 20, no. 3, pp. 313-345, 2005.

[3] B. Davies and P. Bansel, "Neoliberalism and education," International Journal of Qualitative Studies in Education, vol. 20, no. 3, pp. 247-259, 2007.

[4] S. J. Ball, "Show me the money! Neoliberalism at work in education," Forum, vol. 54, no. 1, pp. 23-28, 2012.

[5] M. Baltodano, "Neoliberalism and the demise of public education: the corporatization of schools of education," International Journal of Qualitative Studies in Education, vol. 25, no. 4, pp. 487-507, 2012.

[6] R. Chopra, "Neoliberalism as doxa: bourdieu's theory of the state and the contemporary Indian discourse on globalization and liberalization," Cultural Studies, vol. 17, no. 3-4, pp. 419-444, 2003.

[7] B. Down, "Schooling, productivity and the enterprising self: beyond market values," Critical Studies in Education, vol. 50, no. 1, pp. 51-64, 2009.

[8] R. Torraco, "Writing integrative literature reviews: guidelines and examples," Human Resource Development Review, vol. 4, no. 3, pp. 356-367, 2005.

[9] L. W. Rozas and W. C. Klein, "The value and purpose of the traditional qualitative literature review," Journal of EvidenceBased Social Work, vol. 7, no. 5, pp. 387-399, 2010.

[10] A. Sylvester, M. Tate, and D. Johnstone, "Beyond synthesis: representing heterogeneous research literature," Behaviour and Information Technology, 2012.

[11] S. T. Rocco and S. M. Plakhotnik, "Literature reviews, conceptual frameworks, and theoretical frameworks: terms, functions, and distinctions," Human Resource Development Review, vol. 8, no. 1, pp. 120-130, 2009.

[12] J. Webster and T. Watson, "Analyzing the past to prepare for the future: writing a literature review," MIS Quarterly, vol. 26, no. 2, 2002.

[13] M. Foucault, "About the beginning of the hermeneutics of the self: two lectures at Dartmouth," Political Theory, vol. 21, no. 2, pp. 198-227, 1993.

[14] M. Foucault, "What is Critique?" in The Politics of Truth: Michel Foucault (Translated: L. Hochroth), S. Lotringer and L. Hochroch, Eds., pp. 23-82, Semiotext, New York, NY, USA, 1997.

[15] M. Bevir, "Foucault and critique: deploying agency against autonomy," Political Theory, vol. 27, no. 1, pp. 65-84, 1999.

[16] G. Biesta, "Against learning. Reclaiming a language for education in an age of learning," Nordisk Pedagogik, vol. 25, no. 1, pp. 54-66, 2005.

[17] L. Phillips and S. Ilcan, "Capacity-building: the neoliberal governance of development," Canadian Journal of Development Studies, vol. 25, no. 3, pp. 393-409, 2004.

[18] M. A. Centeno and J. N. Cohen, "The Arc of Neoliberalism," Annual Review of Sociology, vol. 38, pp. 317-340, 2012.

[19] D. W. Hursh and J. A. Henderson, "Contesting global neoliberalism and creating alternative futures," Discourse, vol. 32, no. 2, pp. 171-185, 2011.

[20] M. A. Peters, "Three forms of the knowledge economy: learning, creativity and openness," British Journal of Educational Studies, vol. 58, no. 1, pp. 67-88, 2010.

[21] M. Olssen, "Understanding the mechanisms of neoliberal control: lifelong learning, flexibility and knowledge capitalism," International Journal of Lifelong Education, vol. 25, no. 3, pp. 213-230, 2006.

[22] A. Major, "Neoliberalism and the new international financial architecture," Review of International Political Economy, vol. 19, no. 4, pp. 536-561, 2012.

[23] D. Brancaleone and S. O'Brien, "Educational commodification and the (economic) sign value of learning outcomes," British Journal of Sociology of Education, vol. 32, no. 4, pp. 501-519, 2011.

[24] W. W. Powell and K. Snellman, "The knowledge economy," Annual Review of Sociology, vol. 30, pp. 199-220, 2004.

[25] M. A. Peters, "Classical political economy and the role of universities in the new knowledge economy," Globalisation, Societies and Education, vol. 1, no. 2, pp. 153-168, 2003. 
[26] A. Fumagalli, "Twenty theses on contemporary capitalism (cognitive biocapitalism)," Journal of the Theoretical Humanities, vol. 16, no. 3, pp. 7-17, 2011.

[27] G. Tsogas, "The commodity form in cognitive capitalism," Culture and Organization, vol. 18, no. 5, pp. 377-395, 2012.

[28] M. A. Peters and J. Reveley, "Retrofitting drucker: knowledge work under cognitive capitalism," Culture and Organization, pp. $1-17,2012$.

[29] Department for Education, The overall aims of the National Curriculum, Qualifications and Curriculum Authority, 2011, http://media.education.gov.uk/assets/files/pdf/c/curriculum\% 20aims.pdf.

[30] Scottish Government, Building the Curriculum 4: Skills for learning, skills for life and skills for work, Edinburgh, The Scottish Government, 2009, http://www.scotland.gov.uk/Resource/ Doc/288517/0088239.pdf.

[31] P. Brown and H. Lauder, "Globalisation, knowledge and the myth of the magnet economy," Globalisation, Societies and Education, vol. 4, pp. 25-57, 2006.

[32] M. Priestley and W. Humes, "The development of Scotland's Curriculum for Excellence: amnesia and déjà vu," Oxford Review of Education, vol. 36, no. 3, pp. 345-361, 2010.

[33] C. A. Torres, "Public universities and the neoliberal common sense: seven iconoclastic theses," International Studies in Sociology of Education, vol. 21, no. 3, pp. 177-197, 2011.

[34] I. Kauppinen, "Academic capitalism and the informational fraction of the transnational capitalist class," Globalisation, Societies and Education, pp. 1-22, 2012.

[35] L. Levidow, "Marketizing higher education: neoliberal strategies and counter-strategies," in The Virtual University? Knowledge, Markets and Management, K. Robins, Kevin, and F. Webster, Eds., pp. 227-248, Oxford University Press, Oxford, UK, 2002.

[36] S. Clegg, "Cultural capital and agency: connecting critique and curriculum in higher education," British Journal of Sociology of Education, vol. 32, no. 1, pp. 93-108, 2011.

[37] A. Cribb and S. Gewirtz, "The hollowed-out university? A critical analysis of changing institutional and academic norms in UK higher education," Discourse, pp. 1-13, 2012.

[38] M. Nussbaum, Not for Profit: Why Democracy Needs the Humanities, Princeton University Press, Princeton, NJ, USA.

[39] M. Alvesson, "Knowledge work: ambiguity, image and identity," Human Relations, vol. 54, no. 7, pp. 863-886, 2001.

[40] M. Young, "Education, globalisation, and the 'voice of knowledge," Journal of Education and Work, vol. 22, no. 3, pp. 193-204, 2009.

[41] D. Cahill, "Beyond neoliberalism? Crisis and the Prospects for Progressive Alternatives," New Political Science, vol. 33, no. 4, pp. 479-492, 2011.

[42] E. Staddon and P. Standish, "Improving the student experience," Journal of Philosophy of Education, vol. 46, no. 4, pp. 631-648, 2012.

[43] R. Goddard, "Critiquing the Educational Present: the (limited) usefulness to educational research of the Foucauldian approach to governmentality," Educational Philosophy and Theory, vol. 42, no. 3, pp. 345-360, 2010.

[44] S. Vassallo, "Critical pedagogy and neoliberalism: concerns with teaching self-regulated learning," Studies in Philosophy of Education, 2012.

[45] B. Miller, "Skills for sale: what is being commodified in higher education?" Journal of Further and Higher Education, vol. 34, no. 2, pp. 199-206, 2010.
[46] M. Bonnett, "Education and selfhood: a phenomenological investigation," Journal of Philosophy of Education, vol. 43, no. 3, pp. 357-370, 2009.

[47] S. Ball and A. Olmedo, "Care of the self, resistance and subjectivity under neoliberal governmentality," Critical Studies in Education, vol. 54, no. 1, pp. 85-96, 2013.

[48] A. Wolf, "Education and economic performance: simplistic theories and their policy consequences," Oxford Review of Economic Policy, vol. 20, no. 2, pp. 315-333, 2004.

[49] L. Wacquant, "Critical thought as solvent of doxa," Constellations, vol. 11, no. 1, pp. 97-101, 2004.

[50] J. White, "Education, the market and the nature of personal well-being," British Journal of Educational Studies, vol. 50, no. 4, pp. 442-456, 2002.

[51] R. M. Ryan, V. Huta, and E. L. Deci, "Living well: a selfdetermination theory perspective on eudaimonia," Journal of Happiness Studies, vol. 9, no. 1, pp. 139-170, 2008.

[52] E. L. Deci, R. J. Vallerand, L. G. Pelletier, and R. M. Ryan, "Motivation and education: the self-determination perspective," Educational Psychologist, vol. 26, no. 3-4, pp. 325-346, 1991.

[53] M. Hand, "Against autonomy as an educational aim," Oxford Review of Education, vol. 32, no. 4, pp. 535-550, 2006.

[54] S. Billett, "Lifelong learning and self: work, subjectivity and learning," Studies in Continuing Education, vol. 32, no. 1, pp. 1$16,2010$. 

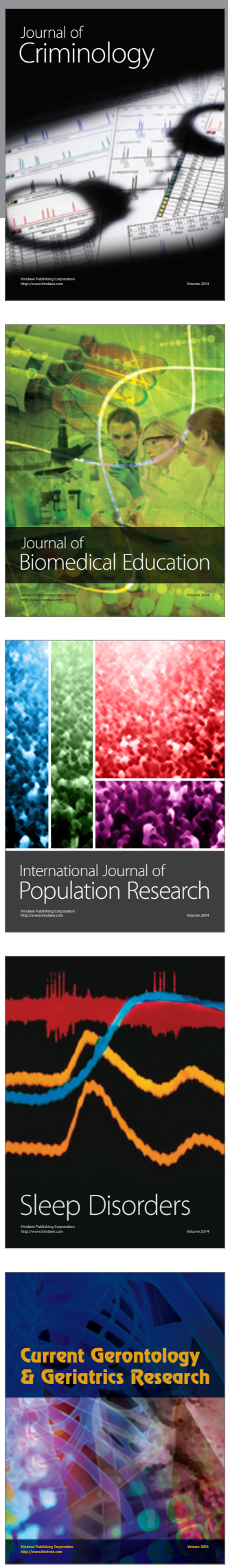
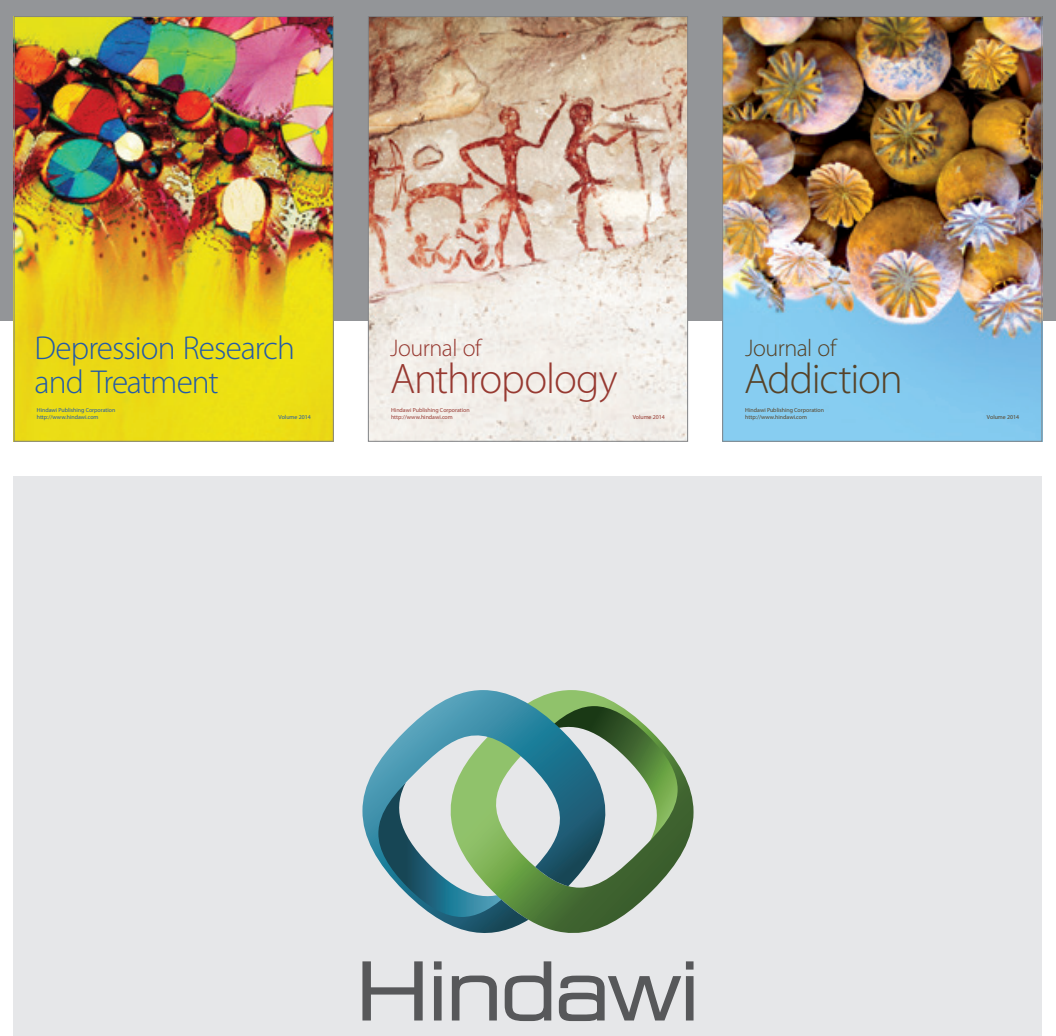

Submit your manuscripts at

http://www.hindawi.com

Child Development Research
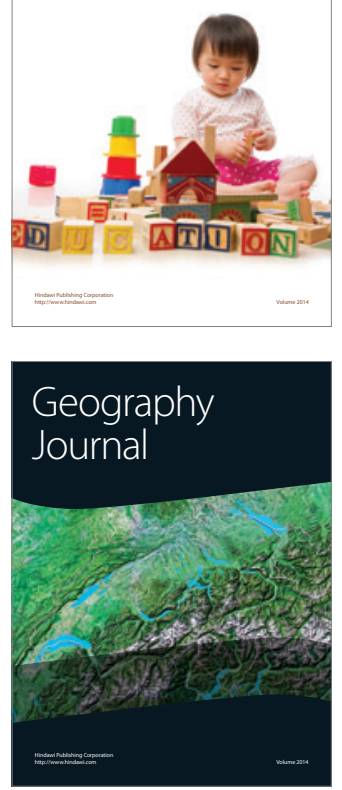

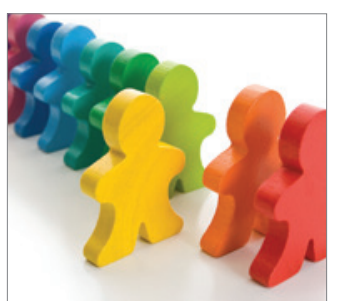

Autism

Research and Treatment
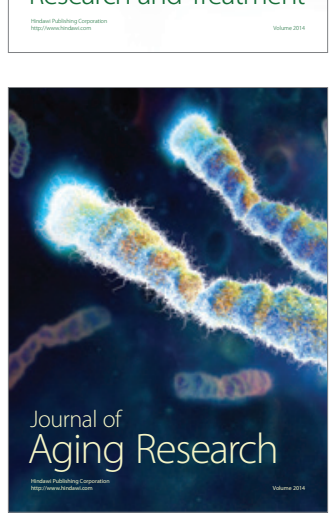
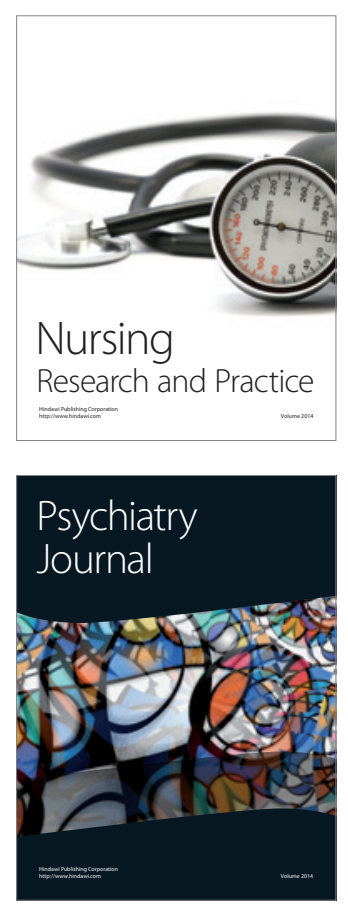
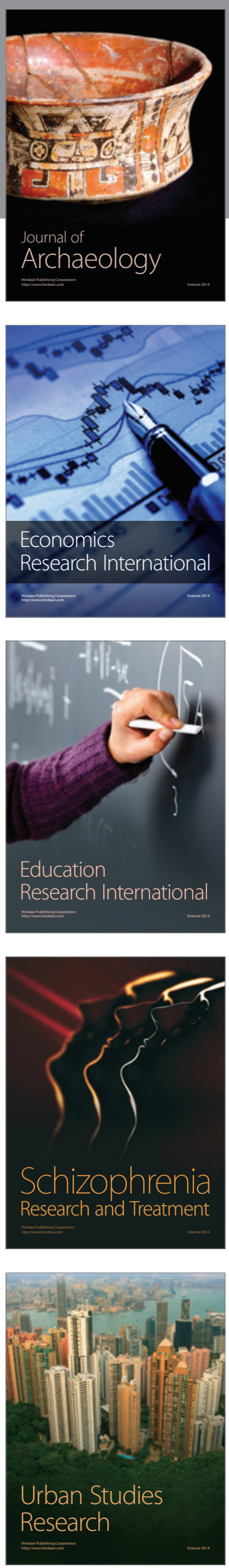